\title{
EFFECT OF MUTAGENS ON SEED PROTEIN AND CARBOHYDRATES CONTENTS OF MORPHOLOGICAL MUTANTS OF COWPEA [VIGNA UNGUICULATA (L.) WALP.]
}

\author{
${ }^{1}$ B. S. Gaikwad* and ${ }^{2}$ A.D. More \\ ${ }^{1}$ Department of Botany, K.J.Somaiya College,Kopargaon,Dist:Ahmednager(M.S.) \\ ${ }^{2}$ Department of Botany, Fergusson College, Pune-411004. \\ *Corresponding Author: bs.gaikwad69@gmail.com
}

Communicated : 25.02.2020

Revision : $19.03 .20 \& 10.4 .2020$

Accepted : 20.05.2020
Published: 30.05 .2020

\begin{abstract}
:
Cowpea [Vigna unguiculata (L.) Walp.] belongs to family Fabaceae. Cowpea is an important grain legume throughout the tropics and subtropics. Cowpea seeds are important source of protein, vitamins and minerals It is one of the most important pulse crops in India. . Cowpea variety- Phule Pandhari (PCP-9708) was used for present research work. The seeds were treated with chemical mutagen like EMS and physical mutagen gamma rays.In the present studies seed protein and carbohydrates were estimated in the morphological viable mutant like Robust mutant, Branched mutant, Dark green mutant, Early flowering mutant, Late flowering mutant,Tall mutant, Dwarf mutant, Bold seeded mutant, Luxuriant mutant and Divergently branched mutantin Cowpea. The estimated value of seed protein and carbohydrates in viable mutant was observed. Induced mutagenesis may bring about changes in the overall morphology of plants and also increase in biochemical nature like carbohydrates, proteins, fats, vitamins and minerals.
\end{abstract}

Key Words: -Cowpea, Gamma rays, EMS, Proteins, Carbohydrates, Mutagens.

\section{INTRODUCTION:}

Cowpea (Vigna unguiculata [L.] Walp. belongs to family Fabaceae. Cowpea is one of the most important pulse crops in India. It is known as Chavali in Marathi. Cowpea provides a dietary protein for the human consumption and plays an important role in Indian subcontinents. The seeds are major source of dietary protein in most developing countries. It contains carbohydrates, proteins, fats, vitamins and minerals. There are twenty two varieties of Cowpea have been recommended for different states and union territory. Cowpea is considered as poor man's food. It is nutritionally cultivated in India for food, fodder, green manure and cover crop. It is low in fat and high content of fiber. The seeds of cowpea contains about $54.5 \%$ of Carbohydrates, $24.1 \%$ of Proteins, vitamin - C of (2.01) Calcium (77), Iron (8.60), Phosphorus (414) providing good nutritional quality.

\section{MATERIALS AND METHODS:}

The experimental seed material of Cowpea (Vigna unguiculata [L]. Walp.) Variety- Phule Pandhari (PCP-9708) was collected from Pulse and oil seed research station, Pandharpur, Dist- Solapur. Released by Mahatma Phule Krishi Vidhyapeeth, Rahuri,Dist-Ahmednagar.

Cowpea [Vigna unguiculata (L.) Walp.] seeds were treated with chemical mutagen Ethyl Methane Sulphonate (EMS) at the concentration of $0.050 \%$, 0.075\%, 0.10\%, 0.125\% and Physical mutagen Gamma rays at the dosage $20 \mathrm{kR}, 30 \mathrm{kR}, 40 \mathrm{kR}$, $50 \mathrm{kR}$.

\section{Estimation of Seed protein:}

Material used: Healthy dry seeds material

\section{Procedure for Extraction:}

For extraction of seed protein, dry seeds were washed with tap water and grinds to them in a fine powder with grinder. The fine powder was used for the extraction of protein by Lowery et al., (1951) method. 


\section{Estimation of protein:}

Principle: This colorimetric method is used to determine the protein contents from the plant materials. This method is very simple and sensitive. It is based on the principle that different proteins and amount of aromatic amino acids like tryptophan and tyrosine. These amino acids reduce the phosphomolybdic-phosphotungstic components in the folin-phenol reagent giving a blue colored product. A bluish purple color is developed by the biuret reaction of the proteins with the alkaline cupric tartarate. The intensity of these colored products is measured calorimetrically or spectophotometricaly at 660 or $750 \mathrm{~nm}$.

\section{Chemicals:}

1. Reagent A: $2 \% \mathrm{Na}_{2} \mathrm{CO}_{3}$ in $0.1 \mathrm{~N} \mathrm{NaOH}$.

2. Reagent B: $0.5 \% \mathrm{CuSO}_{4} .{ }_{0} \mathrm{H}_{2} \mathrm{O}$ in $1 \% \mathrm{Na}-$ K Tartarate.

3. Reagent C: $\operatorname{mix} 49 \mathrm{ml}$ of reagent $\mathrm{A}$ and $1 \mathrm{ml}$ of reagent $\mathrm{B}$ just before use

4. Reagent D: Dilute commercially available Folin-phenol reagent 1:2 with distilled water.

5. Standard protein solution of Bovine serum Albumin.

\section{Procedure:}

Prepared 1 to 8 numbers of test tube as a series of standard protein by pipette solution of BSA from 0.1 to $0.5 \mathrm{ml}$. adjusted the volume in all the tubes to $0.5 \mathrm{ml}$ by addition of appropriated volume of distilled water. Extract was pipette out $0.1 \mathrm{ml}$ and $0.2 \mathrm{ml}$ of protein in test tube no. 7 and 8. Add $5 \mathrm{ml}$ of freshly prepared regent $\mathrm{C}$ in all the tubes. Mix the content thoroughly and incubated the tubes at room temperature for 20 minutes and add $0.5 \mathrm{ml}$ of reagent $\mathrm{D}$ in all the tubes and again incubated them at room temperature for 20 minutes. The absorbance of the samples was recorded at the $750 \mathrm{~nm}$ on a spectrophotometer. Used test tube no.1 (blank) to standardize the instrument. Plot the graph of amount of proteins $\mathrm{v} / \mathrm{s}$ absorbance at $750 \mathrm{~nm}$ and from the graph calculated the amount of proteins present in the sample.

The following formula was used for estimation $0.1 \mathrm{ml}$ of plant extract contains $=\mathrm{X} \mu \mathrm{g}$ protein (from the graph)

$\therefore 10 \mathrm{ml}$ of extract (= total volume of extract) contains $=10 \mathrm{X} / 0.1$

$=\mathrm{Y} \mu \mathrm{g}$ protein

This $10 \mathrm{ml}$ extract was prepared from $0.5 \mathrm{~g}$ of plant material

$\therefore 0.5 \mathrm{~g}$ plant material contains $=\mathrm{Y} \mu \mathrm{g}$ protein

$\therefore 1 \mathrm{~g}$ plant material contains $=\mathrm{Y} / 0.5=\mathrm{Z} \mu \mathrm{g}$ protein

(Source: Sadasivam and Manickam, 2008)

Estimation of carbohydrates by Anthrone method Hedge and Hofreiter, (1962)

Principle:

Carbohydrates hydrolyzed into simple sugars using dilute hydrochloric acid. In hot acidic medium glucose is dehydrated to hydroxymethyl furfural. This green coloured product compound can absorbance of maximum at $630 \mathrm{~nm}$ by Anthrone method.

\section{Procedure:}

Total carbohydrates were estimated by used the Anthrone method. The seed material was crushed into powder and $100 \mathrm{mg}$. powders were hydrolyzed with $5 \mathrm{ml}$ of $2.5 \mathrm{~N} \mathrm{HCl}$ in boiled water in water bath for 3 hours. The digested sample was cooled to room temperature and neutralized by adding sodium carbonate. The final volume was adjusted to $100 \mathrm{ml}$ with distilled water and centrifuged at $5000 \mathrm{rpm}$ for $15 \mathrm{~min}$. Collected supernatant and from the sample 0.5 and $1 \mathrm{ml}$ aliquots used for analysis of total carbohydrates. The green coloured developed in reaction and it was read at $630 \mathrm{~nm}$ UV-visible spectrophotometer. The sugar compound like Dglucose at the concentration of $100 \mathrm{ug}$ ml-1 was used to prepare the standard curve. The amount 
of carbohydrate present was calculated by used following formula.

Amount of carbohydrate present in $100 \mathrm{mg}$ of the sample

mg of glucose X 100

Volume of test sample

(Source: Sadasivam and Manikam, 2008)

\section{RESULTS:}

\section{Seed protein content}

Total seed proteins content were estimated in morphological mutant like 1) Robust mutant 2) Branched mutant 3) Dark green mutant 4) Early flowering mutant 5) Late flowering mutant 6) Tall mutant 7) Dwarf mutant 8) Bold seeded mutant 9) Luxuriant mutant and 10) Divergently branched mutant in Cowpea [Vigna unguiculata (L.) Walp.]. In control plant, estimated value of seeds was $22.19 \%$ of total proteins. The estimated values of seed proteins content for all studied mutants were ranged from $22.83 \%$ to $27.46 \%$. The maximum estimated amount of total seed proteins content was $27.46 \%$ in luxuriant mutant, while the minimum estimated amount of total seed proteins content $22.83 \%$ was estimated in Dwarf mutant. The estimated values of morphological viable mutants for total seed proteins content was to be found maximum values in Luxuriant mutant followed by Late flowering mutant and Robust mutant. The majority of viable mutants showed positive shift in mean value against the control.

\section{Carbohydrates content}

Carbohydrates content in viable mutants of Cowpea ranges from $1.79 \%$ to $5.58 \%$. In control plant $2.33 \%$ total carbohydrate was found. The highest $5.58 \%$ total carbohydrates was observed in dwarf mutant and lowest $1.79 \%$, total carbohydrates content was found in branched mutant

\section{DISCUSSION:}

Seed proteins content in the present investigation have revealed an enhancement in majority of morphological viable mutants observed in the $\mathrm{M}_{4}$ generation in Cowpea [Vigna unguiculata (L.) Walp.]. These morphological viable mutant like 1) Robust mutant 2) Branched mutant 3) Dark green mutant 4) Early flowering mutant 5) Late flowering mutant 6) Tall mutant 7) Dwarf mutant 8) Bold seeded mutant 9) Luxuriant mutant and 10) Divergently branched mutant induced by EMS and Gamma rays mutagenic treatments in Cowpea [Vigna unguiculata (L.) Walp.]. A positive shift of mean value in seed protein content recorded in majority of viable mutants. Total estimated proteins content in seed was slight higher than control. The estimated seed proteins were observed in highest values in high yielding mutants. The estimated seed proteins content in high yielding mutant showed positive shift in mean value over the control after mutagenic treatments with EMS, Gamma rays. For the improvement of proteins content in seed material through genetic approach can be a reliable source. Efforts are required for the manipulation of various protein components in the seed of crops. Mertz et al., (1964) reported that the genetic alteration of protein quality can be considered as useful technique for the rapid removal of protein malnutrition. In recent years, the protein synthesis in seeds was regulated by a series of specific genes in the proteins due to genetic alterations in most of the pulses crops.

The total seed protein content and protein pattern with relative proportions of the protein groups was influenced by the different mutant genes by Gottschalk and Muller, (1970).

In present estimation of seed proteins in different viable mutants of Cowpea the seed protein content was gradually increased with increases in dose/concentration of EMS and Gamma ray treatments against control were 
reported by Arulbalchandran and Mullainathan, (2009) in Black gram.

The similar result was reported by many researchers like Jijiya, 1986 and Sudharani, (1990) and Desai and Rao, (2014). Tah, (2006) reported increased seed protein content in two varieties of Mungbean against the control. Auti and Apparao, (2008) estimated the seed protein content in viable mutants of Mungbean. Wani and Anis, (2008) studied that the reduction in protein content of bold seeded in high yielding mutant of Chickpea. Pavadai et al., (2010) reported the enhancements in seed protein content of Soybean. Sri Devi and Mullainathan, (2012) recorded that in increased seed protein content of mutant in Black gram.

\section{Carbohydrates contents}

The total carbohydrate was estimated in different morphological viable mutants observed in the $\mathrm{M}_{4}$ generation. These morphological viable mutant like 1) Robust mutant 2) Branched mutant 3) Dark green mutant 4) Early flowering mutant 5) Late flowering mutant 6) Tall mutant 7) Dwarf mutant 8) Bold seeded mutant 9) Luxuriant mutant and 10) Divergently branched mutant induced by EMS, Gamma rays and Combination of both mutagens treatments in Cowpea [Vigna unguiculata (L.) Walp.].The carbohydrate estimated values in majority of viable mutants showed positive shift in mean against control and four types of viable mutants was estimated negative values as against to the control.

\section{CONCLUSION:}

The seed protein content in the present studies has revealed an enhancement in majority of the $\mathrm{M}_{4}$ generation. The viable mutants have developed through the EMS and gamma rays treatments. Total carbohydrates content in morphological viable mutants of Cowpea ranges from $1.79 \%$ to $5.58 \%$. It can be said that various chemical and physical mutagenic treatments employed in the present research work have been

succeeded in inducing superior genotypes with significant alterations in growth and metabolism of the plant body. The mutagens successfully induced genetic variability and different mutants of agronomic traits. The results obtained are quite encouraging to utilize the mutants recovered for obtaining better seed protein content besides improved yield in case of Cowpea. Five mutants like robust, dark green leaves, tall, bold and large seeded and luxuriant mutants are showing better yield contributing parameters and even more seed protein as compare to control. Such mutants could be promoted for cultivation after successful completion of seed certification.

\section{REFERENCES:}

Arulbalachandran, D. and Mullainathan, L. (2009). Chlorophyll and Morphological mutants of Black Gram (Vigna mungo (L.) Hepper) derived by gamma rays and EMS. J Phytol. 1(4): 236-241.

Arvindhan, S. and Das, L.D.V. (1996) Heterosis and combining ability in fodder cowpea for green fodder and seed yield. Madras Agricultural Journal 83:11-14.

Auti, S.G. and Apparao, B.J. (2008) Mutagen induced variability in Protein content of Mungbean.Journal of Food Legumes. 21(3):161-162.

Baldev, B., Ramanujam, S. and Jain, H. K. (1988) Pulse Crops (Grain Legumes). Oxford and IBH Publishing Co. Pvt. Ltd.

Desai, A.and Rao,S.(2014) Effect of gamma radiation on germination and physiological aspects of Pigeonpea [Cajanus cajan(L.)Millsp.]seedlings. International Journal of Applied, Natural and Social Science. Vol. 2, 47-52. 
Daly, K. (1960) The induction of quantitative variability induced by gamma radiation in Arabidopsis thaliana. Genetics. 45: 983.

Gottschalk, W. and Muller, H.P. (1970) Monogenic alteration of seed protein content and protein pattern in X-ray induced Pisum mutants from improving Plant protein by Nuclear Techniques. IAEA, Vienna, 201215.

Jijiya, B.B. (1986) Mutation breeding in Phaseolus vulgaris (L.) Ph.D. Thesis Osmania University, Hyderabad.

Lowry, O. H., Rosebrough, N. J., Farr, A. L. and Randall, R. J. (1951) Protein measurement with the Folin phenol reagent. J. Biol. Chem. 193: 265.

Mertz, E. T., Bates, L. S. and Nelson, O. E. (1964) Science. 145:279. [Quoted by H. C. Bansal and M. L. Lodha. In:Induced Mutations for Improving Nutritional Quality in Crop Plant”. Proc.of Symp. on The Role of Induced Mutations in Crop Improvement", Hyderabad, Sept. 1979, 148-160.]

Pavadai, P., Girija, M. and Dhanavel, D. (2010) Effect of gamma rays on some yield parameters and protein content of Soybean in $\mathrm{M}_{2}, \mathrm{M}_{3}$ and $\mathrm{M}_{4}$ generation. $J$ Exp Sci. 1(6): 08-11.

Sadasivam, S. and Manickam, A. (2008) Biochemical methods, New Age International (P.) Ltd., Publishers New Delhi, 3rd Edition.

Sri Devi, A. and Mullainathan, L. (2012) Effect of gamma rays and ethyl methane sulphonate (EMS) in $\mathrm{M}_{3}$ generation of Blackgram (Vigna mungo L. Hepper). Afr. J. Biotechnol. 11(15): 3548- 3552.

Sudha Rani, T. (1990) Genetical studies in induced mutants of Phaseolus mungo L.Ph.D. Thesis, Osmania University.

[15] Tah, P.R.(2006)Studies on gamma rays induced mutations in Mungbean[Vigna radiata (L.)Wilczek.]Asian Journal of Plant Sciences.5(1):61-70.

Wani, A.A. and Anis, M. (2008) Gamma Rays and EMS Induced Bold-Seeded High-yielding Mutants in Chickpea (Cicer arientinum L.). Turk J Biol. 32: 161-166. 
I J R B A T, Issue (VIII), Vol. II, May 2020: 26-31

Table no. 1. Seed protein and carbohydrates content of the morphological mutants of Cowpea

\begin{tabular}{|l|c|c|}
\hline \multicolumn{1}{|c|}{$\begin{array}{c}\text { Morphological } \\
\text { Mutants }\end{array}$} & $\begin{array}{c}\text { Seed } \\
\text { protein } \\
\text { content \% }\end{array}$ & $\begin{array}{c}\text { Carbohydrates } \\
\text { content \% }\end{array}$ \\
\hline Control & 22.19 & 2.33 \\
\hline Robust Mutant & 25.44 & 2.44 \\
\hline Branched Mutant & 24.71 & 1.79 \\
\hline $\begin{array}{l}\text { Dark Green } \\
\text { Mutant }\end{array}$ & 25.10 & 2.09 \\
\hline $\begin{array}{l}\text { Early flowering } \\
\text { Mutant }\end{array}$ & 24.67 & 2.08 \\
\hline $\begin{array}{l}\text { Late flowering } \\
\text { Mutant }\end{array}$ & 26.45 & 2.13 \\
\hline Tall Mutant & 25.11 & 4.02 \\
\hline Dwarf Mutant & 22.83 & 5.58 \\
\hline $\begin{array}{l}\text { Bold seeded } \\
\text { Mutant }\end{array}$ & 23.86 & 3.42 \\
\hline Luxuriant Mutant & 27.46 & 3.03 \\
\hline $\begin{array}{l}\text { Divergently } \\
\text { Branched Mutant }\end{array}$ & 23.01 & 2.53 \\
\hline
\end{tabular}
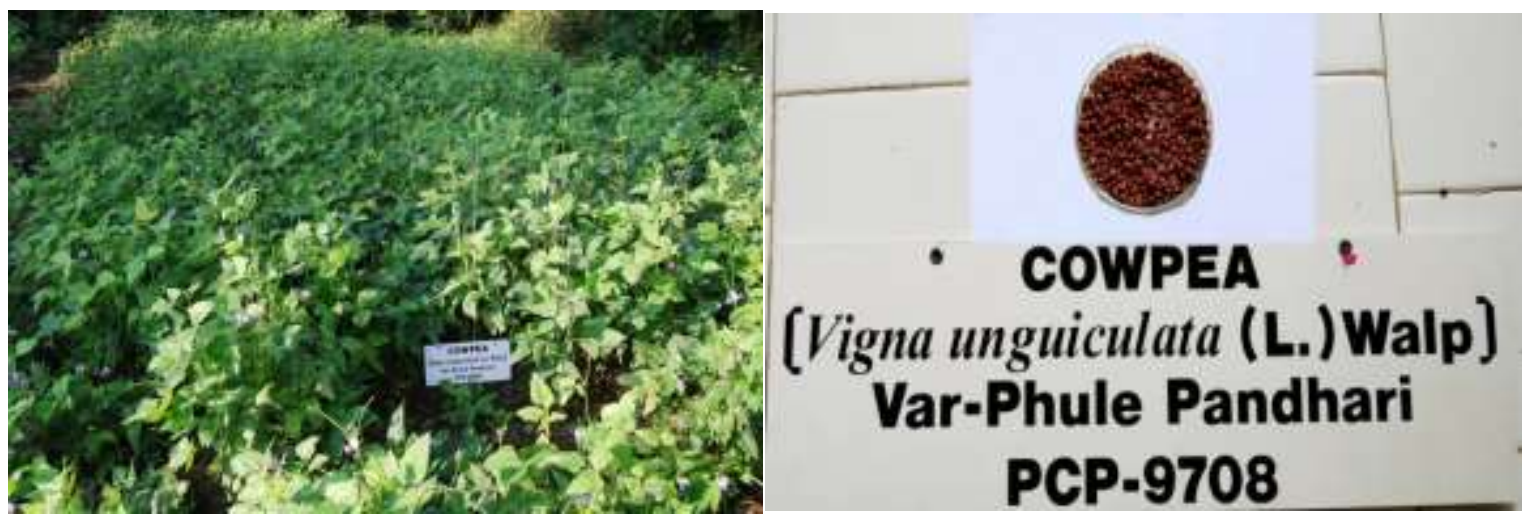